\title{
Antimicrobial, Antioxidant Activities and Total Phenolic Contents of the Traditional Turkish Beverages Produced by Using Grapes\#
}

\author{
Gülten Tiryaki Gündüz ${ }^{1, a, *}$, Ayça Korkmaz Vurmaz ${ }^{1, b}$, Ezgi Solak ${ }^{1, c}$, Hande Didar Sözbir $^{1, d}$ \\ ${ }^{1}$ Department of Food Engineering, Faculty of Engineering, Ege University, Bornova, 35040 Izmir, Turkey
}

*Corresponding author

A R T I C L E I N F O
\#This study was presented as
presentation at the 4th Intern
Anatolian Agriculture, Food,
Environment and Biology Co
(Afyonkarahisar, TARGID 20
Research Article
Received : 27/06/2019
Accepted : 12/09/2019

Keywords:
Grapes
Hardaliye
Traditional beverages
Antimicrobial
Antioxidant activity

A B S T R A C T

In the present study, antimicrobial effects of traditional beverages produced from grapes such as traditional grape pickles, grape juice, home-made hardaliye, and commercially produced hardaliye were investigated using microdilution method against Staphylococcus aureus ATCC 6538P, Escherichia coli ATCC 25922, Salmonella Typhimurium NRRL B4420, Bacillus cereus ATCC 10876, Saccharomyces cerevisiae NRRL Y12632, Lactobacillus acidophilus La-5 and L. rhamnosus LGG. In addition, total phenolic content was measured by the Folin-Ciocalteau method, and antioxidant activities of grape products were evaluated using DPPH assay. Results showed that grape containing beverages have antimicrobial effects on S. aureus, E. coli, S. typhimurium and B. cereus at various minimum inhibitory concentration (MIC) values in the range of 4.53$150 \mathrm{mg} / \mathrm{mL}$. The lowest MIC value of $4.53 \mathrm{mg} / \mathrm{mL}$ was obtained against $E$. coli for home-made hardaliye. MIC values of the traditional grape pickles were determined as $4.69 \mathrm{mg} / \mathrm{mL}$ and $9.38 \mathrm{mg} / \mathrm{mL}$ against S.aureus and E.coli, respectively. On the other hand, traditional grape pickles showed weak inhibitory effects against B.cereus with MIC value of $150 \mathrm{mg} / \mathrm{mL}$. The bactericidal effect of these grape products was not detected for any of the test microorganisms however traditional foods produced by using grapes were showed inhibitory effects at different concentrations against tested microorganisms except for probiotics and the yeast. The total phenolic contents of the grape products were within the range of 865.27-2193.08 $\mathrm{mg}$ gallic acid equivalent (GAE)/L. Free radical scavenging activities of grape samples ranged from $46 \%$ to $90 \%$ and the grape juice was found to have the highest antioxidant activity. In conclusion, grape beverages have the potential to act as a antimicrobial and antioxidant agents for use as a natural antimicrobial and antioxidant product in the food industry.

Türk Tarım - Gida Bilim ve Teknoloji Dergisi 7(sp1): 119-125, 2019

\section{Üzüm Kullanılarak Üretilen Geleneksel Türk İçeceklerinin Antimikrobiyal, Aktioksidan Etkileri ve Toplam Fenolik İçerikleri}

\begin{tabular}{|c|c|}
\hline M A K A LE B İ L G İ S İ & Ö Z \\
\hline $\begin{array}{l}\text { Anahtar Kelimeler: } \\
\text { Üzüm } \\
\text { Hardaliye } \\
\text { Geleneksel içecekler } \\
\text { Antimikrobiyal } \\
\text { Antioksidan aktivite }\end{array}$ & 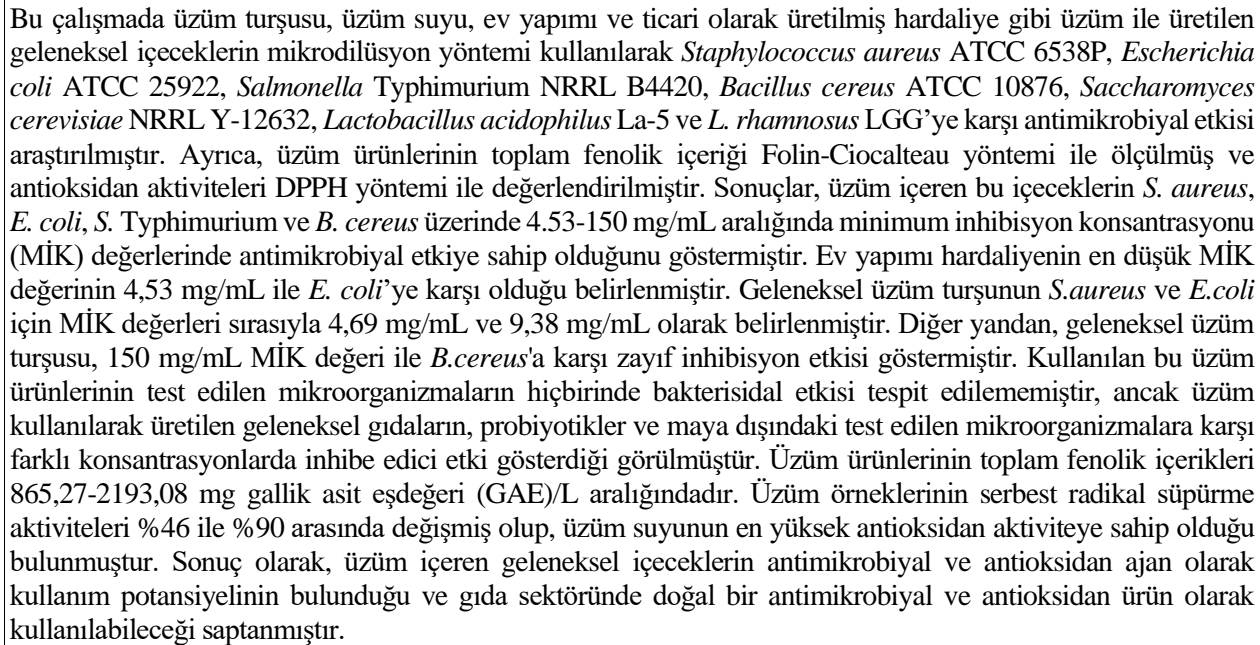 \\
\hline
\end{tabular}




\section{Introduction}

Grapes (Vitis vinifera L.) are one of the commercially important fruit worldwide. Grapes are one of the main natural sources of phenolic compounds, therefore it has been associated with substantial health benefits such as antioxidant, anti-carcinogenic, cardioprotective and anti-inflammatory properties (Toaldo et al., 2014). Harvest dates of grapes are closely connected to the timing of grape maturation and which is not available throughout the year (Cook and Wolkovich, 2016). Generally, grapes are consumed either raw or in processed form. The beverages produced by using grapes are a good opportunity for consumers who want to consume grapes all seasons (Coskun, 2017). Grape juice is a fresh and nutritious beverage containing minerals, vitamins and phenolics (Faria et al., 2016).

Grapes are rich in phenolic compounds, such as flavonoids (catechin, epicatechin, quercetin, anthocyanins and procyanidins), and resveratrol, which are mainly found in red grape products (Dani et al., 2007). These compounds have been identified and quantified in several fruits and vegetables and show a high correlation with antioxidant activity (Soares, 2002; Einbond et al., 2004; Pehlivan and Sevindik, 2018). Moreover, these polyphenol compounds have been proved to show various biological effects such as antioxidant or antimicrobial (Jayaprakasha et al., 2003; Baydar et al., 2006; Sevindik et al., 2017). Grape juice consumption in the world has increased significantly in recent years (Spinelli et al., 2016). Grape pickle is a traditional fermented beverage made by adding molasses, horseradish (Armoracia rusticana P. Gaertn., B. Mey. \& Scherb.) roots and grapes in the Thrace region of Turkey. Hardaliye is a grapefruit based a non-alcoholic traditional beverage in the Thrace region of Turkey. Hardaliye is mostly manufactured homemade by the traditional method. Red grape (Papazkarasi, Alphonse or Cardinal) or grape juice, $0.2 \%$ of crushed raw mustard seeds, sour cherry leaves and $0.1 \%$ of benzoic acid are mixed in preferably in wooden (or plastic) barrel for the production of hardaliye and then the mix is fermented for 5-10 days. After fermentation, the ingredients are filtered and hardaliye is stored at $4^{\circ} \mathrm{C}$ for 3-4 months (Arici and Coskun, 2001; Altay et al., 2013; Amoutzopoulos et al., 2013; Marsh et al., 2014; Panghal et al., 2018). Hardaliye is a valuable, traditional beverage due to it is highly delicious, nonalcoholic, non-dairy and low-fat that is used in the nutrition of a wide range of consumer groups including children, vegetarians, people with a dairy intolerance (Amoutzopoulos et al., 2013).

Interest in the use of natural substances to prevent microbiological spoilage of food has significantly increased in the last years, due to the high demand of high nutritional value and safe foods (Soliva-Fortuny and Martín-Belloso 2003; Raybaudi-Massilia et al., 2009). The development of alternative food products for the preservation of microbiological quality continues and traditional natural products are considered as good alternatives. The objective of this study was to evaluate the antimicrobial, the antioxidant activities and total phenolic contents of different types of traditional Turkish beverages produced using grapes.

\section{Materials and methods}

Samples

In this study, traditional beverages produced from grapes such as traditional grape pickles, grape juice, supernatant from the grape juice, home-made hardaliye and commercially produced hardaliye were used. The home-made hardaliye was obtained by a producer who produces the traditional hardaliye for their own consumption. Commercially produced hardaliye was purchased from a local market in Kırklareli. Grape pickle samples were produced in our laboratory according to traditional procedures. Grape juice samples were provided from Samsun, Turkey and used in two different ways. One grape juice sample was used as it was and for the second sample, the grape juice was centrifuged at $4,000 \times \mathrm{g}$ for 10 min for the experiments and the supernatant was used. All the test materials were filtered through a $0.45 \mu \mathrm{m}$ cellulose acetate filter (Minisart, Sartorius) directly to an amber coloured bottle. Sterile test samples were stored at $4^{\circ} \mathrm{C}$.

\section{$p H$ and ${ }^{\circ}$ Brix Values of the Beverages}

Total soluble solid content $\left({ }^{\circ}\right.$ Brix) of samples was measured using a refractometer. The $\mathrm{pH}$ values were determined by a digital $\mathrm{pH}$ meter (NEL Mod 821).

\section{Total Phenolic Content of The Beverages}

The total phenolic contents of the beverages were determined spectrophotometrically at $760 \mathrm{~nm}$ according to the Folin-Ciocalteu colorimetric method (Singleton and Rossi, 1965). Estimations were carried out in triplicate and calculated from the standard curve was prepared with gallic acid. Total phenolics were expressed as gallic acid equivalents (mg GAE/mL).

\section{Free Radical-Scavenging Ability (DPPH)}

The free radical-scavenging ability of grape products was also studied through the evaluation of the free radicalscavenging effect on the 1,1-diphenyl-2-picrylhydrazyl (DPPH) radical. The DPPH assay was determined using the modified method of Singh et al. (2002). The sample $(0.1 \mathrm{~mL})$ was pipetted into $5 \mathrm{~mL}$ of $0.1 \mathrm{mM} \mathrm{DPPH}$ methanolic solution to initiate the reaction. The mixture was thoroughly vortex-mixed and kept in the dark for 15 min. The absorbance was measured later, at $517 \mathrm{~nm}$ using the Agilent Technologies Cary 60 UV-Vis, against a blank of methanol without DPPH. Results were expressed as a percentage of inhibition of the DPPH radical. Percentage of inhibition of the DPPH radical was calculated according to the following equation:

$$
\% \text { Inhibition of DPPH }=\left(\frac{\text { Abs control-Abs sample }}{\text { Abs control }}\right) \times 100
$$

where Abs control is the absorbance of DPPH solution without samples.

\section{Test Cultures and Culture Preparations}

The antimicrobial activity of products was assessed against six bacteria: Staphylococcus aureus ATCC 6538P, Escherichia coli ATCC 25922, Salmonella Typhimurium NRRL B4420, Bacillus cereus ATCC 10876, 
Lactobacillus acidophilus La-5, L. rhamnosus LGG and the yeast Saccharomyces cerevisiae NRRL Y-12632. The test cultures were subcultured twice before the inoculation. Bacterial cultures were inoculated into Tryptone Soya Broth (TSB, pH 7.3 \pm 0.2 , Oxoid) and incubated at $37^{\circ} \mathrm{C}$ for $24 \mathrm{~h}$ and for the studied yeast Malt Extract Broth (MEB, $\mathrm{pH} 4.6 \pm 0.2$, Merck) was used and incubated at $30^{\circ} \mathrm{C}$ for 24 h. Activated (18-24 h) microbial cells were collected by centrifugation $\left(4000 \times \mathrm{g}, 10 \mathrm{~min}, 4^{\circ} \mathrm{C}\right)$ and re-suspended in sterile peptone water $(0.1 \%)$, and then microbial suspensions were adjusted to $0.5 \mathrm{McFarland}$ scale from this suspension (Romulo et al., 2018). Total microbial count in the standard inoculum was determined using the spread plate technique. Appropriate dilutions were prepared and inoculated on TSA and MEA plates for bacteria and yeast, respectively. Inoculated plates were incubated at $37^{\circ} \mathrm{C}$ for 24-48 hours for bacteria and at $30^{\circ} \mathrm{C}$ for $3-5$ days for yeast.

\section{Determination of Antimicrobial Activity}

The antibacterial activities of samples were determined by using a microdilution method and the minimum inhibitory concentrations of grape products were determined. Different culture media of Mueller Hinton Broth (MHB), de Man, Rogosa and Sharpe (MRS) Broth and Malt Extract Broth (MEB) were used for the bacteria, the two probiotics and the yeast, respectively. The minimum inhibitory concentration of products against microorganisms was carried out by broth microdilution method using sterile 96-well cell culture microplates. The 96-well plates were prepared by dispensing into each well $100 \mu \mathrm{L}$ of broth medium except first wells and $200 \mu \mathrm{L}$ from the sample was added into the first wells. Then, $100 \mu \mathrm{L}$ from their serial dilutions was transferred into consecutive wells. For the determination of antimicrobial activity, cultures were adjusted to $0.5 \mathrm{McFarland}$ turbidity standard. Microplates were inoculated with respective microbial culture suspension and then incubated at $37^{\circ} \mathrm{C}$ for $24 \mathrm{~h}$ for bacteria and $30^{\circ} \mathrm{C}$ for $48 \mathrm{~h}$ for yeast (No et al., 2002; Jung et al., 2010). The microplates were tested for the absence or presence of visible growth in comparison with that in negative control wells. At the end of the incubation, the microbial growth was indicated by the presence of a white "pellet" on the well bottom and an effective growth indicator for use of dye reagents by 2,3,5-Triphenyltetrazolium chloride (TTC) or the resazurin (Balouiri et al., 2016). The minimum inhibitory concentration (MIC) was determined as the lowest concentration of an antimicrobial agent that prevents visible growth of a microorganism in broth dilution susceptibility test. The minimum bactericidal concentration was defined as the lowest concentration at which there was no microbial growth. The minimum bactericidal concentration (MBC) was determined by inoculation of a loopful from each clear well onto agar plates (Filocamo et al., 2015).

\section{Results and Discussion}

In the present study, the antimicrobial effects of traditional grape-containing products on Gram-positive and Gram-negative bacteria, two probiotics and yeast were investigated. The $\mathrm{pH}$ and ${ }^{\circ} \mathrm{Brix}$ values of the samples are also determined (Table 1). Total soluble solids ( ${ }^{\circ}$ Brix) of the different samples showed differences ranged from $14 \%$ to $60 \%$ and the $\mathrm{pH}$ values of samples ranged from 3.00 to
5.36. The lowest $\mathrm{pH}$ value (3.00) was observed for grape juice compared to the other samples.

Most studies have shown that grapes are a rich source of phenolic compounds and these compounds have been proved to show a variety of biological effects, including antioxidant, anticarcinogenic, anti-inflammatory and antimicrobial activities (Baydar et al., 2004; Baydar et al., 2006, Jayaprakasha et al., 2003; Monagas et al., 2003; Serra et al., 2008). For this reason, total phenolic compounds in the beverages have been determined to find out the relationship between antimicrobial activity and phenolic compound content. There are many reports about the antimicrobial activity of the phenolic compound of different food sources against microorganisms. Mohammed et al. (2018) reported that Rhus coriaria var. zebaria had high antimicrobial activity levels at different concentrations between $25-100 \mu \mathrm{g} / \mathrm{mL}$. It was considered that antioxidant, antimicrobial, DNA protective and cytotoxic effects of $R$. coriaria var. zebaria were attributed to the phenolic contents. Similarly, Pehlivan and Sevindik (2018) were determined antioxidant and antimicrobial activities of Salvia multicaulis Vahl plant against the test microorganisms including S.aureus, Enterococcus faecalis and E.coli. However, there are no available reports on the inhibitory effects on microorganisms of traditional Turkish beverages produced by using grapes. Table 2 gives the total phenolic contents of the beverages evaluated by the Folin-Ciocalteu colorimetric method. As shown in Table 2, total phenolic compounds of commercially produced hardaliye were more than the others, while total phenolic compounds of grape juice and grape pickles samples were lower than hardaliye samples.

Table 1 Total soluble content $\left({ }^{\circ} \mathrm{Brix}\right)$ and $\mathrm{pH}$ values of beverages

\begin{tabular}{l|cl}
\hline \multicolumn{1}{c|}{ Test materials } & ${ }^{\circ}$ Brix & $\mathrm{pH}$ \\
\hline Grape pickles & 60 & 5.36 \\
Supernatant from the grape juice & 14 & 3.08 \\
Grape juice & 15 & 3.00 \\
Home-made hardaliye & 14.5 & 3.82 \\
Commercially produced hardaliye & 19 & 3.66 \\
\hline
\end{tabular}

Table 2 Total phenolic content of beverages

\begin{tabular}{l|c}
\multicolumn{1}{c|}{ Test materials } & $\begin{array}{c}\text { Total phenolic } \\
\text { content }(\mathrm{mg} / \mathrm{L})^{*}\end{array}$ \\
\hline Grape pickles & $865.27(17.63)$ \\
Supernatant from the grape juice & $1701.97(6.63)$ \\
Grape juice & $1515.27(2.84)$ \\
Home-made hardaliye & $2029.30(4.53)$ \\
Commercially produced hardaliye & $2193.08(2.25)$ \\
\hline
\end{tabular}

*Values are shown as means $(n=5)$ and standard deviations are given in parenthesis.

Total phenolic contents of hardaliye samples are between 2029.30 and $2193.08 \mathrm{mg} / \mathrm{L}$. According to da Silva Padilha (2017), the total phenolic content varied from 2135 to $2647 \mathrm{mg} / \mathrm{L}$ for the grape juices. However, the total phenolic content obtained in this study is not in line with those mentioned in grape juices. Samples of grape juice presented values of phenolic contents smaller than those reported in the literature for several samples of grape juice, whose average values ranged from 1515.27 to 1701.97 
mg/L (Burin et al., 2010; Margraf et al., 2016). In similar studies on total phenolic content in grape juices using the Folin-Ciocalteu method carried out by Frankel et al. (1998), the results for Concord grape juice ranged between 1654-1971 mg/L and for juices produced with a greater variety of grapes, the total phenolic content range was 1407-1541 mg/L. According to Frankel et al. (1998) mention that the phenolic contents of grape juice may be influenced by the geographical origin of grapes, the procedures employed in the juice production and reactions occurring during storage (Granato et al., 2016).

The minimum inhibitory concentration (MIC) and minimum bactericidal concentration (MBC) values of grape products for microorganisms were determined for the evaluation of the antimicrobial activity (Table 3). Results indicated that the grape pickles showed lowest antibacterial activity against $B$. cereus $(\mathrm{MIC}=150 \mathrm{mg} / \mathrm{mL})$, on the other hand, the highest antibacterial activity was obtained against $S$. aureus (MIC=4.69 mg/mL). Göral (2019) investigated the survival of Escherichia coli and Bacillus cereus in grape pickles. For this purpose, E.coli and B.cereus inoculated into grape pickles at two levels of $10^{3} \mathrm{CFU} / \mathrm{mL}$ and $10^{6} \mathrm{CFU} / \mathrm{mL}$. E. coli cells were not determined after one week. On the other hand, the population of B.cereus were found in the range of 1.56$1.72 \mathrm{CFU} / \mathrm{g}$ at the end of the storage period of 5 months.

In many studies, the inhibitory effects of many plant extracts were attributed to their acidity (Gutierrez et al., 2009; Mohammed et al., 2018). In the present study, there is no difference between the samples of grape juice and supernatant from the grape juice in their $\mathrm{pH}$ values. MICs of supernatant from the grape juice against the $S$. Typhimurium and E. coli were 8.75 and $17.5 \mathrm{mg} / \mathrm{mL}$, respectively. According to the MIC values for supernatant of the grape juice, higher antimicrobial activities were obtained at lower concentrations against test microorganisms, compared to the grape juice. The difference of antimicrobial activity between grape juice and supernatant of the grape juice was considered due to the variation in the phenolic profile of samples. Also, this result suggests there might be a positive antimicrobial effect within the constituents of the supernatant of grape juice that reinforce the inhibition response and/or the natural compound contains other components in the matrices with antimicrobial activity (Serra et al., 2008).

Table 3 The minimum inhibitory concentration (MIC) and the minimum bactericidal concentration (MBC) values of test materials against the microorganisms tested in microdilution assay

\begin{tabular}{|c|c|c|c|c|c|c|c|c|c|c|}
\hline \multirow{3}{*}{ Microorganisms } & \multicolumn{10}{|c|}{ Test materials $(\mathrm{mg} / \mathrm{mL})$} \\
\hline & \multicolumn{2}{|c|}{ Grape pickles } & \multicolumn{2}{|c|}{$\begin{array}{l}\text { Supernatant } \\
\text { from the grape } \\
\text { juice }\end{array}$} & \multicolumn{2}{|c|}{ Grape juice } & \multicolumn{2}{|c|}{$\begin{array}{l}\text { Home-made } \\
\text { hardaliye }\end{array}$} & \multicolumn{2}{|c|}{$\begin{array}{c}\text { Commercially } \\
\text { produced } \\
\text { hardaliye }\end{array}$} \\
\hline & MIC & $\mathrm{MBC}$ & MIC & $\mathrm{MBC}$ & MIC & $\mathrm{MBC}$ & MIC & $\mathrm{MBC}$ & MIC & $\mathrm{MBC}$ \\
\hline S. aureus & 4.69 & - & 35 & - & 37.5 & - & 36.25 & - & 47.5 & - \\
\hline E. coli & 9.38 & - & 17.5 & - & 37.5 & - & 4.53 & - & 11.88 & - \\
\hline$S$. Typhimurium & 37.5 & - & 8.75 & - & 18.75 & - & 18.13 & - & 23.75 & - \\
\hline B. cereus & 150 & - & 17.5 & - & 18.75 & - & 18.13 & - & 23.75 & - \\
\hline S. cerevisiae & $-^{\mathrm{a}}$ & - & $-b$ & - & $-c$ & - & $-d$ & - & $-\mathrm{e}$ & - \\
\hline L. acidophilus & ${ }^{\mathrm{a}}$ & - & $-b$ & - & $-^{c}$ & - & $-d$ & - & $-\mathrm{e}$ & - \\
\hline L. rhamnosus & $-^{\mathrm{a}}$ & - & $-^{\mathrm{b}}$ & - & $-^{c}$ & - & $\mathrm{-}^{\mathrm{d}}$ & - & $-^{\mathrm{e}}$ & - \\
\hline
\end{tabular}

$-_{-}^{\mathrm{a}}$ : No inhibition activity in the tested maximum concentration of $300 \mathrm{mg} / \mathrm{mL},-^{\mathrm{b}}$ : No inhibition activity in the tested maximum concentration of 70 $\mathrm{mg} / \mathrm{mL},-_{-}^{-}$: No inhibition activity in the tested maximum concentration of $75 \mathrm{mg} / \mathrm{mL},{ }_{-}^{\text {dd: }}$. No inhibition activity in the tested maximum concentration of $72.5 \mathrm{mg} / \mathrm{mL},-_{-}^{-}$: No inhibition activity in the tested maximum concentration of $95 \mathrm{mg} / \mathrm{mL}$, -: No bactericidal activity in the tested concentrations.

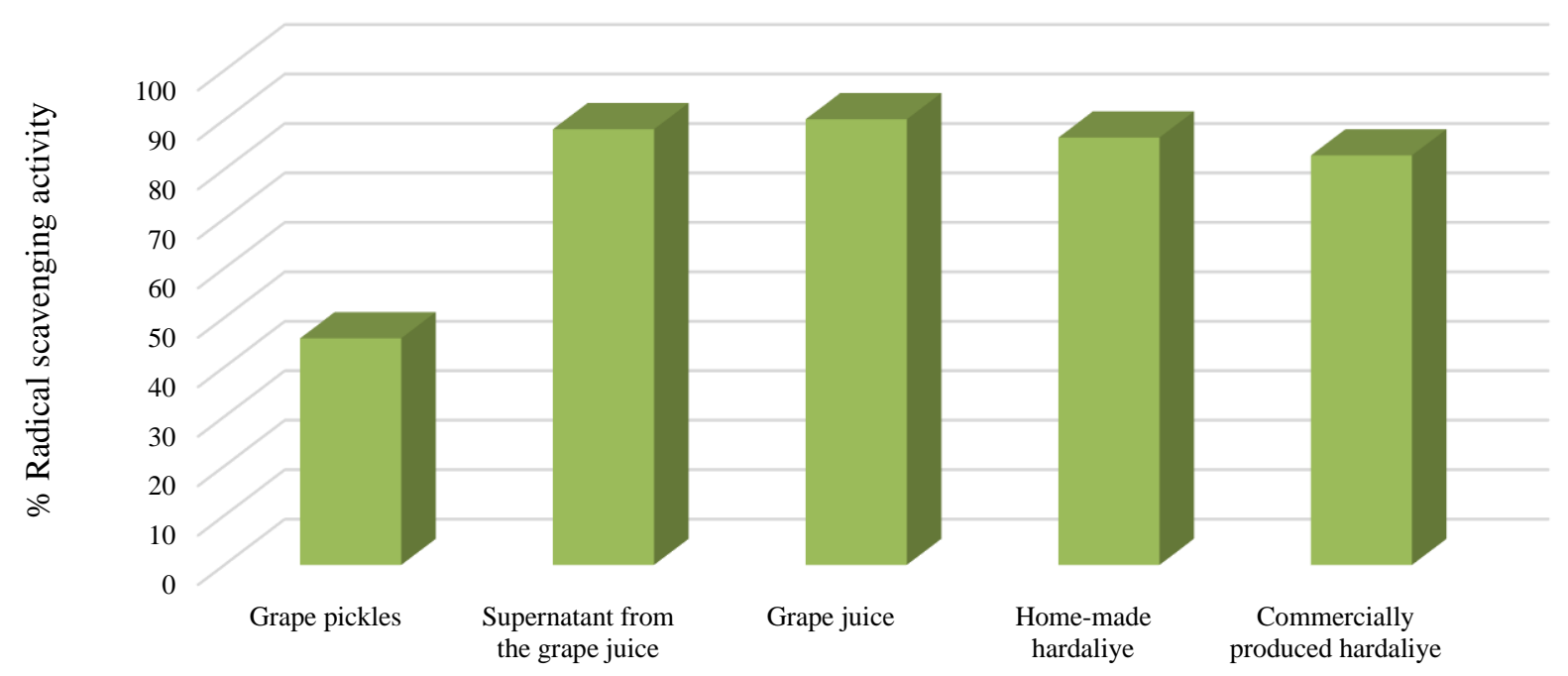

Figure 1 Radical scavenging activity of samples by DPPH method 
Hardaliye is a grape beverage considered to have antioxidative effects as a potential source of bioactive components (Amoutzopoulos, 2013). The $\mathrm{pH}$ values of commercially produced and home-made hardaliye samples used in this study were 3.66 and 3.82, respectively. Similar $\mathrm{pH}$ values were obtained in the study conducted by Arici and Coskun (2001). Total soluble contents are higher in the commercially produced hardaliye compared with homemade hardaliye (Table 1). In this study, the total phenolic content in the commercially produced hardaliye was also higher than those found in the home made hardaliye. Similarly, the data reported by Coşkun et al. (2018) total polyphenol content from 368.8 to $2647.5 \mathrm{mg}$ / L was found in the hardaliye samples. MIC value of the home-made hardaliye sample were lower than that of commercially produced hardaliye samples. The home-made hardaliye has the strongest antimicrobial activity, with a MIC of 4.53 $\mathrm{mg} / \mathrm{mL}$ against E. coli. Home-made hardaliye exhibited significant antibacterial activity against $E$. coli compared to commercially produced hardaliye, and those results contrast to higher polyphenolic content existent in the commercially produced hardaliye. Commercially produced hardaliye had been shown to be antibacterial against $E$. coli, S. Typhimurium, B. cereus and S. aureus with MICs of $11.88,23.75,23.75$ and $47.5 \mathrm{mg} / \mathrm{mL}$, respectively. On the other hand, no inhibitory effect on the growth of probiotic bacteria and the yeast was detected. Pehlivanoglu et al. (2015) reported that the antimicrobial effect of hardaliye against E. coli and Listeria monocytogenes. Similar to those obtained in this study, hardaliye samples has no antimicrobial effects on $S$. cerevisiae. Also, the bactericidal effect of these grape products was not detected at the tested concentrations for any of the test microorganisms (Table 3).

The antimicrobial effect of various fruit and vegetable juices were studied many times and the primary reasons for inhibition of microorganisms are concluded as organic acids and phenolic compounds in these materials (Öncül and Karabıyıkl1, 2016). The juice of grapes was found to be highly inhibitory against Listeria species. The grape juice reduced the number of initial cells $\left(10^{6}-10^{7} \mathrm{CFU} / \mathrm{mL}\right)$ of L. monocytogenes to an undetectable level after $10 \mathrm{~min}$ of application (Rhodes et al., 2006). Additionally, Serra et al. (2008), reported that the grape aqueous extract had high phenolic compounds and had a good antimicrobial potential against Bacillus cereus, $S$. cerevisiae and $C$. albicans. Sanhueza et al. (2014), have reported an antibacterial effect of grape pomace extracts mainly against $S$. aureus and $E$. coli due to the polar phenolic content of grapes. Filocamo et al. (2015) have demonstrated that the MIC values of white grape juice extract ranged from 3.9 to $>2000 \mu \mathrm{g} / \mathrm{mL}$. Among the Gram-positive bacteria, S.aureus showed the highest sensitivity, with MIC and MBC values equal to 3.9 and 500 $\mu \mathrm{g} / \mathrm{mL}$, respectively (Filocamo et al., 2015). Similarly, a good growth inhibitory effect was found against S.aureus with a MIC value of $4.69 \mathrm{mg} / \mathrm{mL}$ in the present study.

Commercially produced hardaliye was contained the highest phenolic compound (Table 2). In many studies, it was reported that the inhibitory effects of phenolic compounds from natural extracts are more potent to Grampositive bacteria than Gram-negative (Jayaprakasha et al., 2003, Furiga et al., 2009, Kao et al., 2010; Adámez et al.,
2012). On the other hand, grape pickle has strong antimicrobial activity, with a MIC of $9.38 \mathrm{mg} / \mathrm{mL}$ against E. coli.

Free radical scavenging potentials of samples were tested by the DPPH method, and the results are shown in Figure 1. The greater the DPPH radical consumption associated with the higher the antioxidant activity of the sample (Miliauskas et al., 2004). The DPPH antioxidant activity of grape products were high for all samples, except in grape pickles, in this study. Grape pickles were considerably less effective radical scavengers compared to other beverages produced by using grapes. Samples of grape product exhibit free radical scavenging activities in the range of $46-90 \%$ (Figure 1). The results indicated that beverages produced by using grapes were free radical inhibitors and the most active radical scavengers were obtained for the grape juice.

The antioxidant capacity of samples generally associated with the presence of a mixture of polyphenolic compounds with good antioxidant properties (Adámez et al., 2012). In the case of this study, there may be a slight correlation between phenolic content and antioxidant activity. Differences in the antioxidant and antimicrobial activities among grape products were attributed to their different phenolic contents and compositions and to other non-phenolic antioxidants present in the samples (Dávalos et al., 2005). Recently, scientific investigations around the world have focused on traditional fermented food products. Turkey has a wide range of traditional fermented beverages. The results of the present study demonstrated that traditional grape products have an inhibitory effect against $S$. aureus, E. coli, $S$. Typhimurium and B. cereus. Data showed that all samples inhibited the growth of all tested microorganisms except probiotics and yeast. Grape products may have a potential role as a natural preservative for pathogenic microorganisms and also could be used as an additive for the probiotic beverages. Further studies need to be performed to better assess the antimicrobial effects of grape-based beverages produced by traditional procedures.

\section{References}

Adámez JD, Samino EG, Sánchez EV, González-Gómez D. 2012. In vitro estimation of the antibacterial activity and antioxidant capacity of aqueous extracts from grape-seeds (Vitis vinifera $\mathrm{L}$.). Food Control 24(1-2): 136-141. DOI: 10.1016/j.foodcont. 2011.09.016.

Altay F, Karbancioglu FG, Daskaya CD, Heperkan D. 2013. A review on traditional Turkish fermented non-alcoholic beverages: microbiota, fermentation process and quality characteristics. Int. J. Food Microbiol. 167(1): 44-56.DOI: 10.1016/j.ijfoodmicro.2013.06.016.

Amoutzopoulos B, Löker GB, Samur G, Çevikkalp SA, Yaman M, Köse T, Pelvan E. 2013. Effects of a traditional fermented grape-based drink 'hardaliye' on antioxidant status of healthy adults: a randomized controlled clinical trial. J. Sci. Food Agric. 93(14): 3604-3610. DOI: 3604-3610. 10.1002/jsfa.6158.

Arici M, Coskun F. 2001. Hardaliye: Fermented grape juice as a traditional Turkish beverage. Food Microbiol. 18(4): 417421. DOI: $10.1006 /$ fmic.2001.0413.

Balouiri M, Sadiki M, Ibnsouda SK. 2016. Methods for in vitro evaluating antimicrobial activity: A review. J. Pharm. Biomed. Anal. 6(2): 71-79. DOI: 10.1016/j.jpha. 2015.11.005. 
Baydar NG, Özkan G, Sağdiç O. 2004. Total phenolic contents and antibacterial activities of grape (Vitis vinifera $\mathrm{L}$.) extracts. Food Control 15(5): 335-339. DOI: 10.1016/S09567135(03)00083-5.

Baydar NG, Sagdic O, Ozkan G, Cetin S. 2006. Determination of antibacterial effects and total phenolic contents of grape (Vitis vinifera L.) seed extracts. Int .J. Food Sci. Technol. 41(7): 799-804. DOI: 10.1111/j.1365-2621.2005.01095.x.

Burin VM, Falcão LD, Gonzaga LV, Fett R, Rosier JP, Bordignon-Luiz MT. 2010. Colour, phenolic content and antioxidant activity of grape juice, Food Sci. Technol. 30(4): 1027-1032. DOI: 10.1590/S0101-20612010000400030.

Cook BI, Wolkovich EM. 2016. Climate change decouples drought from early wine grape harvests in France. Nat. Clim. Change. 6(7): 715-719. DOI: 10.1038/NCLIMATE2960.

Coskun F. 2017. A traditional Turkish fermented non-alcoholic grape-based beverage, "Hardaliye". Beverages, 3(2): 1 -11. DOI: $10.3390 /$ beverages 3010002 .

Coşkun F, Arıcı M, Gulcu M, Çelikyurt G, Mırık M. 2018. Physicochemical, functional and microbiological properties of hardaliye beverages produced from different grapes and collected from different households. J. Agric. Sci. 24(2): 278285. DOI: $10.15832 /$ ankutbd.446458.

da Silva Padilha CV, Miskinis GA, de Souza MEAO, Pereira GE, de Oliveira, D., Bordignon-Luiz MT, dos Santos Lima M. 2017. Rapid determination of flavonoids and phenolic acids in grape juices and wines by RP-HPLC/DAD: Method validation and characterization of commercial products of the new Brazilian varieties of grape. Food Chemistry, 228: 106115. DOI: 10.1016/j.foodchem.2017.01.137.

Dani C, Oliboni LS, Vanderlinde R, Bonatto D, Salvador M, Henriques JAP, 2007. Phenolic content and antioxidant activities of white and purple juices manufactured with organically-or conventionally-produced grapes. Food Chem. Toxicol. 45(12): DOI: 2574-2580. 10.1016/j.fct.2007.06.022.

Dávalos A, Bartolomé B, Gómez-Cordovés C. 2005. Antioxidant properties of commercial grape juices and vinegars. Food Chemistry, 93(2): 325-330. DOI: 10.1016/j.foodchem. 2004.09.030

Einbond LS, Reynertson KA, Luo XD, Basile MJ, Kennelly EJ. 2004. Anthocyanin antioxidants from edible fruits. Food Chemistry, 84: 23-28. DOI: 10.1016/S0308-8146(03)00162-6.

Faria SBA, de Souza VR, Dias JF, Moreira NX, de Azeredo, VB. 2016. Effect of grape juice consumption on antioxidant activity and interleukin- 6 concentration in lactating rats. Nutr. Hosp. 33(6): 1418-1420. DOI: 10.20960/nh.804.

Filocamo A, Bisignano C, Mandalari G, Navarra M. 2015. In vitro antimicrobial activity and effect on biofilm production of a white grape juice (Vitis vinifera) extract. J. Evid. Based Complementary Altern. Med. 1-5. DOI: 10.1155/2015/ 856243.

Frankel EN, Bosanek CA, Meyer AS, Silliman K, Kirk LL. 1998. Commercial grape juices inhibit the in vitro oxidation of human low-density lipoproteins. J. Agric. Food Chem. 46(3): 834-838. DOI: 10.1021/jf9707952.

Furiga A, Lonvaud-Funel A, Badet C. 2009. In vitro study of antioxidant capacity and antibacterial activity on oral anaerobes of a grape seed extract. Food Chem. 113(4): 10371040. DOI: 10.1016/j.foodchem.2008.08.059.

Göral S. 2019. Production of grape pickle using Lactobacillus acidophilus and investigating the inhibition effect of the product on Escherichia coli and Bacillus cereus, Ege University, Graduate School of Natural and Applied Science, MSc in Food Engineering, Izmir, Turkey.

Granato D, de Magalhães Carrapeiro M, Fogliano V, van Ruth SM. 2016. Effects of geographical origin, varietal and farming system on the chemical composition and functional properties of purple grape juices: A review. Trends Food Sci Technol. 52: 31-48. DOI: 10.1016/j.tifs.2016.03.013.
Gutierrez J, Barry-Ryan C, Bourke P. 2009. Antimicrobial activity of plant essential oils using food model media: Efficacy, synergistic potential and interactions with food components. Food Microbiol. 26(2): 142-150. DOI:10.1016/j.fm.2008.10.008.

Jayaprakasha GK, Selvi T, Sakariah KK. 2003. Antibacterial and antioxidant activities of grape (Vitis vinifera) seed extracts. Food Res. Int. 36(2): 117-122. DOI:1016/S09639969(02)00116-3.

Jung EJ, Youn DK, Lee SH, No HK, Ha JG, Prinyawiwatkul W. 2010. Antibacterial activity of chitosans with different degrees of deacetylation and viscosities. Int. J. Food Sci. Technol. 45(4): 676-682. DOI: 10.1111/j.1365-2621.2010. 02186.x.

Kao TT, Tu HC, Chang WN, Chen BH, Shi YY, Chang TC, Fu TF. 2010. Grape seed extract inhibits the growth and pathogenicity of Staphylococcus aureus by interfering with dihydrofolate reductase activity and folate-mediated onecarbon metabolism. Int. J. Food Microbiol. 141(1-2): 17-27. DOI: 10.1016/j.ijfoodmicro.2010.04.025.

Margraf T, Santos ÉNT, de Andrade EF, van Ruth SM, Granato D. 2016. Effects of geographical origin, variety and farming system on the chemical markers and in vitro antioxidant capacity of Brazilian purple grape juices. Food Res. Int. 82: 145-155. DOI:1016/j.foodres.2016.02.003.

Marsh AJ, Hill C, Ross RP, Cotter PD. 2014. Fermented beverages with health-promoting potential: past and future perspectives. Trends Food Sci. Technol. 38(2): 113-124. DOI: 10.1016/j.tifs.2014.05.002.

Miliauskas G, Venskutonis PR, van Beek TA. 2004. Screening of radical scavenging activity of some medicinal and aromatic plant extracts. Food Chem. 85(2): 231-237. DOI: 10.1016/j.foodchem.2003.05.007.

Mohammed FS, Akgul H, Sevindik M, Khaled BMT. 2018. Phenolic content and biological activities of Rhus coriaria var. zebaria. Fresen. Environ. Bull. 27(8): 5694-5702.

Monagas M, Gómez-Cordovés C, Bartolomé B, Laureano O, Ricardo da Silva JM. 2003. Monomeric, oligomeric, and polymeric flavan-3-ol composition of wines and grapes from Vitis vinifera L. Cv. Graciano, Tempranillo, and Cabernet Sauvignon. J. Agric. Food Chem. 51(22): 6475-6481. DOI: 10.1021/jf030325+

No HK, Park NY, Lee SH, Meyers SP. 2002. Antibacterial activity of chitosans and chitosan oligomers with different molecular weights. Int. J. Food Microbiol. 74(1-2): 65-72. DOI: 10.1016/S0168-1605(01)00717-6.

Öncül N, Karabıyıklı Ş. 2016. Survival of foodborne pathogens in unripe grape products. LWT-Food Sci. Technol. 74: 168175. DOI: $10.1016 / j .1 w t .2016 .07 .043$.

Panghal A, Janghu S, Virkar K, Gat Y, Kumar V, Chhikara N. 2018. Potential non-dairy probiotic products-A healthy approach. Food Biosci. 21: 80-89. DOI: 10.1016/j.fbio.2017.12.003.

Pehlivan M, Sevindik M. 2018. Antioxidant and antimicrobial activities of Salvia multicaulis. Turkish Journal of Agriculture-Food Science and Technology 6(5): 628-631.

Pehlivanoğlu H, Gündüz HH, Özülkü G, Demirci M, Demirci M. 2015. An investigation of antimicrobial activity of wheat grass juice, barley grass juice, hardaliye and boza. Int. J. Sci Res. 2(1): 8-14. ISSN: 2200-9833.

Raybaudi-Massilia RM, Mosqueda-Melgar J, Soliva-Fortuny R, Martín-Belloso O. 2009. Control of pathogenic and spoilage microorganisms in fresh-cut fruits and fruit juices by traditional and alternative natural antimicrobials. Compr. Rev. Food Sci. Food Saf. 8(3): 157-180. DOI: 10.1111/j.1541-4337.2009.00076.x.

Rhodes PL, Mitchell JW, Wilson MW, Melton LD. 2006. Antilisterial activity of grape juice and grape extracts derived from Vitis vinifera variety Ribier. Int. J. Food Microbiol. 107(3): 281-286. DOI: 10.1016/j.ijfoodmicro.2005.10.022. 
Romulo A, Zuhud EAM, Rondevaldova J, Kokoska L. 2018. Screening of in-vitro antimicrobial activity of plants used in traditional Indonesian medicine. Pharm. Biol. 56(1):287-293. DOI: 10.1080/13880209.2018.1462834.

Sanhueza L, Tello M, Vivanco M, Mendoza L, Wilkens M. 2014. Relation between antibacterial activity against food transmitted pathogens and total phenolic compounds in grape pomace extracts from Cabernet Sauvignon and Syrah varieties. J. Adv. Microbiol. 4(5): 225-232. DOI: 10.4236/aim.2014.45029.

Serra AT, Matias AA, Nunes AV, Leitão MC, Brito D, Bronze R, Silva S, Pires A, Crespo MT, San Ramoa MV, Duarte CM. 2008. In vitro evaluation of olive-and grape-based natural extracts as potential preservatives for food. Innov. Food Sci. Emerg. Technol. 9(3): 311-319. DOI: 10.1016/j.ifset.2007.07.011.

Sevindik M, Akgul H, Pehlivan M, Selamoglu Z. 2017. Determination of therapeutic potential of Mentha longifolia ssp. longifolia. Fresen. Environ. Bull. 26(7): 4757-4763.

Singh RP, Chidambara Murthy KN, Jayaprakasha GK. 2002. Studies on the antioxidant activity of pomegranate (Punica granatum) peel and seed extracts using in vitro models. J. Agric. Food Chem. 50(1): 81-86. DOI: 10.1021/jf010865b.
Singleton VL, Rossi JA. 1965. Colorimetry of total phenolics with phosphomolybdic-phosphotungstic acid reagents. Am. J. Enol. Vitic. 16(3), 144-158.

Soares SE. 2002. Ácidos fenólicos como antioxidantes. Revista de Nutrição, 15(1): 71-81. ISSN: 1415-5273.

Soliva-Fortuny RC, Martín-Belloso O. 2003. New advances in extending the shelf-life of fresh-cut fruits: a review. Trends Food Sci Technol. 14(9): 341-353. DOI: 10.1016/S09242244(03)00054-2.

Spinelli FR, Dutra SV, Carnieli G, Leonardelli S, Drehmer AP, Vanderlinde R. 2016. Detection of addition of apple juice in purple grape juice. Food Control 69: 1-4. DOI: 10.1016/j.foodcont.2016.04.005.

Toaldo IM, de Gois JS, Fogolari O, Hamann D, Borges DL, Bordignon-Luiz MT. 2014. Phytochemical polyphenol extraction and elemental composition of Vitis labrusca $L$. grape juices through optimization of pectinolytic activity. Food Bioprocess Tech. 7(9): 2581-2594. DOI: 10.1007/s11947-014-1288-8. 